\title{
The Discursive Construction of Global Economic Strategies in Turbulent Times
}

\author{
Mustafa $\mathrm{Ar}^{1}$ \\ ${ }^{1}$ Department of English Language Education, Ar-Raniry State Islamic University, Aceh, Indonesia \\ Correspondence: Mustafa Ar, Department of English Language Education, Ar-Raniry State Islamic University, Banda \\ Aceh 23111, Indonesia.
}

Received: June 28, 2016

Accepted: July 12, 2016

Available online: August 17, 2016

doi:10.11114/ijsss.v4i10.1701

URL: http://dx.doi.org/10.11114/ijsss.v4i10.1701

\begin{abstract}
The trajectory of global economy in the first quarter of the twenty-first century was intercepted by the financial meltdown. State leaders advanced their arguments on the issue. Consequently, discourse as a particular moment of economic practices plays a salient role in the social processes of reconstructing a new global economy. The crisis has given rise to a scientific inquiry concerning the interface between the discursive process and social material process in manifesting the global economy. By referring to critical discourse analysis as a transdisciplinary research approach, this paper attempts to identify the global economic strategies and how these strategies are discursively constituted in economic texts during the global financial market crises of 2008-2011. One newspaper Opinion-Editorial article and four political economic speeches by state leaders provide resources of data for the study. The paper identifies three crucial global economic strategies discursively constructed in the social material processes of global economy in turbulent times. These economic strategies are embedded within practical arguments on the current global economic situation, value assumptions, and lexical choices.
\end{abstract}

Keywords: discourse, global economy, critical discourse analysis, transdisciplinary dialogue, competition, reform, turbulent times

\section{Introduction}

Global economy can be embedded in discourse and is politically determined. It is arguably an ideologically motivated economic practice of globalization involving discourse which is produced and naturalized by the proponent states, globalist individuals, governmental and non-governmental agencies and organizations. Consequently, since the rise of globalization era in the second half of the twentieth century, the relationship between language (discourse) as a form of social structure and globalization as an economic phenomenon has been more salient in the transformation, restructuring and re-scaling of global issues. For example, during the 2008-2011 global economic crises, state leaders advanced their own arguments to seek new ways to restructure the global economy. This exemplifies my point that discourse plays a significant role in representing particular social reality such as the global economic policy. It also illustrates that discourse is politically and socially constructed. For instance, a political speech as specific semiosis may constructs a particular political economic perspective that ultimately brings about social transformations in the contemporary global society. The interrelationship between discourse as an element of the social practices and the new global economic agenda in these turbulent times thus becomes a scientific inquiry in language-based critical social science.

The real-estate bubble of the 2000s, subprime mortgages, and audacious financial engineering practices such as excessive lending precipitated the 2008 global financial crisis that is difficult for recovery. This economic turmoil gives rise to supposedly new economic strategies such as the structural reform of financial institutions in both developed and developing countries (Shiller, 2008; Crotty, 2009). The United States as a developed country and China as an emerging economic country, for instance, have probably set up essential strategies in coping with the global economic processes in the turbulent times. Their state leaders as politicians attempt to provide solutions to the economy in the downturn through discourse. As a result, to cope with the recession, language as a means of constituting socioeconomic practices is of considerable importance in ensuring potential solutions to the global financial problems and establishing new strategies of the global economy. This is because economic strategies are always articulated in and through discourse 
(Jessop, 2002; Fairclough, 2006). In other words, global economy has discursive character and is politically constituted. Therefore, when dealing with globalizing processes of economy, it is necessary to refer to language and political economy. The social processes of economic form of globalization and political economy have a dialectical relationship. By means of critical social inquiry (e.g. critical discourse analysis), this dialectical relationship provides us with strong understanding of global economy as both textual and social material processes.

This introduction section will take the opportunity to recap previous literature on discourse and the global economy in turbulent times. There are a few studies that focus on the global financial crisis in the context of discourse analysis and interrelated disciplines. For example, Fairclough \& Fairclough (2011) investigated the UK government's response to the economic crisis in the 2008 pre-budget report. They were concerned with the quest of incorporating argumentation theory into critical discourse analysis (CDA). The study was specifically aimed at bringing practical reasoning to CDA so that the discipline provides further contribution to the development of critical social science. Their analysis of the corpus of the UK government's response to the economic crisis suggests that practical reasoning should be incorporated into CDA to better understand the discursive processes of a social problem. Meanwhile, Lischinsky (2011) used corpus linguistics to investigate how economic actors construct the financial crisis in annual reports from 75 large Swedish companies. He refers to 50 documents released by the companies. The quantitative analysis shows that the crisis is strongly associated with abstract, macroeconomic aggregates and less with stakeholders. The qualitative analysis reveals that many of the concordances are abstract nominalizations concealing the social actors.

Recently few other scholars have also been interested in the discourse of economic crisis (De Ville \& Orbie, 2014; Kelsey, Mueller, Whittle \& KhosraviNik, 2016). De Ville \& Orbie (2014) investigated the European Union (EU)'s trade policy discourse between 2008-2012 financial-economic crises. Their analysis shows that the EU's trade discourse has been adapted to the changing crisis environment. They identify four subtle changes of the EU's trade policy discourse: defensive, offensive-desirable, offensive-necessary and necessary-but-not-sufficient. They argue that the EU trade Commissioners' discourses between 2008 and 2012 have continued to legitimize neoliberal trade through subtle re-articulations of the relationship between free trade and the crisis. They assert that theoretically the study contributes to CDA as well as the EU studies. In a similar vein, Kelsey et al. (2016) examined the discourse of financial crisis and austerity programs as the domain of an interdisciplinary research project. Their analysis is based on the frameworks of rhetoric, storytelling, and political economy to explain the ideological dynamics of social and financial discourse. The study reveals that the reforms of banking sector and austerity programs are often represented through moral mechanisms of storytelling and rhetoric. Politically, national austerity programs are also contextualized with the global financial crisis.

This article is also concerned with the financial crisis from a CDA perspective as an interdisciplinary approach to language-based social research. Nevertheless, it focuses on a different theme and larger scale, that is, the discursive construction of global economic strategies during the 2008-2011 global financial crises. It will concentrate on the economic strategies of the United States and China as representations of the world countries for the global economic research during the crisis. In addition, this study has a different set of objectives, hypotheses, and research questions and resorts to political economy, systemic functional linguistics, and state theory that commit a dialogue within CDA as an interdisciplinary study in critical social science. This article has three main objectives as follows:

1) The study attempts to identify the global economic strategies constructed discursively during the financial crisis.

2) The study aims to describe how these global economic strategies are constructed in discourse.

3) The study represents an attempt to explain the opaque relationship between the discursive process and the global economic strategies in turbulent times.

This study has a set of hypotheses. First, discourse on a particular topic within the global economic crisis is shaped to construct new economic and political strategies. Second, these strategies are raised from a stock of global economic issues. Third, the text also discursively constructs the state economic policy. To explore these assumptions, we need to work on some specific research questions and provide coherent answers. Thus, the analysis of the extracts of texts is guided by the following research questions: what global economic strategies are highly desirable in turbulent times? How are these strategies represented by state leaders in political economic texts? These research questions together with the objectives constitute the goals and guidelines of the study.

\section{Theoretical Framework}

This article draws upon critical discourse analysis (CDA) as the constructivist critical science for investigating the relationship between discourse and global economic strategies in turbulent times. Social constructivism is adhered to a stance that the world around us is socially and textually constructed (Fairclough, 2010). The role of critical science is to provide people with resources for saying and doing things. As a political project, critical science is aimed at "altering inequitable distributions of economic, cultural and political goods in contemporary societies" (Kress, 1996, p. 15). 
Since a social transformation constitutes the major goal of doing critical science, a most suitable conceptual framework for this scientific inquiry is an explanatory critique (Bhaskar, 1986). The explanatory critique belongs to part of critical inquiry that can be in the form of critical realism (Fairclough, 2006; Sayer, 2000). The aim of explanatory critique is to reflect on the social problem at issue and provide solutions for the society with the medium of language (Chouliaraki \& Fairclough, 1999). Schematically, the diagram in Figure 1 below represents the inclusive theoretical rationale of the study.

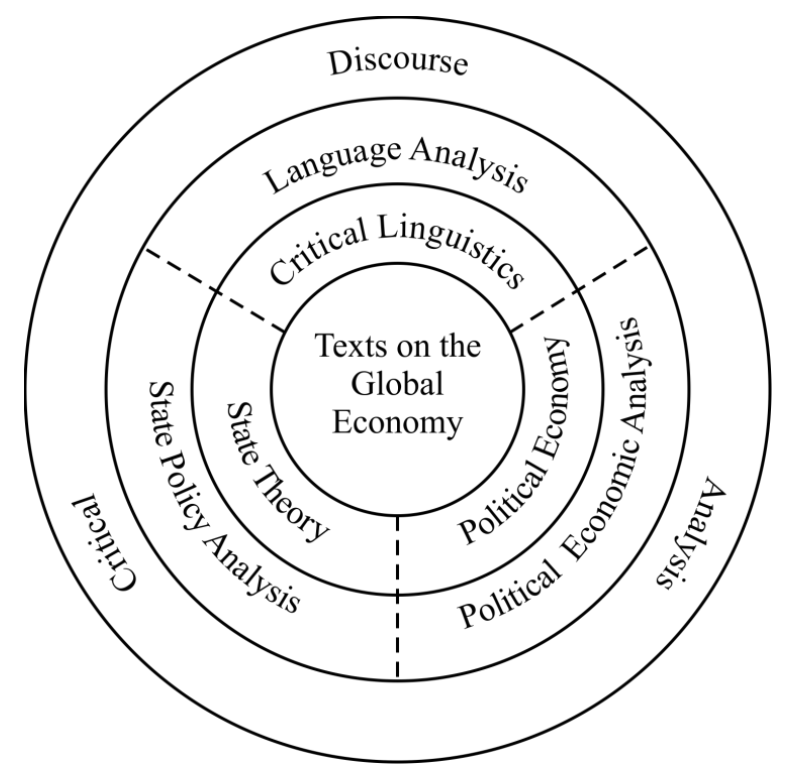

Figure 1. Critical Discourse Analysis within Transdisciplinary Dialogue

This schematic diagram is modeled upon an amalgamation of various ideas from Fairclough (2006); Jessop (2004); Yu (2015); Jessop (2002); Halliday \& Matthiessen (2014), which creates CDA as a transdisciplinary study. Fairclough (2006) sees discourse as a moment of social practices, articulated by social agents within human activities including economy and politic. Discourse can contribute to constituting, transforming imaginaries into realities or merely maintaining the status quo. Theorizing state from philosophy of language perspective, Yu points out that state is conceptualized through linguistic processes. He argues that the use of language and the development of linguistic communication underlie the establishment of governments, states and economic, political and social institutions. Jessop (2002) argues that political economy play a vital role in rescaling the economy and spaces (national, regional, and global). Meanwhile, Jessop (2004) and (Sum \& Jessop, 2015) focus on the semiotic dimension of political economy; they contend that the economy is culturally and politically constructed. Nonetheless, their approach to semiotic and cultural political economic analysis is somewhat in abstract. The framework needs to be supported by language analysis involving systemic linguistics and argumentation analysis. The diagram is therefore stimulated by Hallidayan systemic functional linguistics (SFL) which studies language according to three fundamental functions of language: ideational metafunction, interpersonal metafunction, and textual metafunction (Halliday \& Matthiessen, 2014). The ideational metafunction is concerned with construing our experience of the world, which can be manifested as knowledge or ideology. The interpersonal metafunction is concerned with the enactment of identity (e.g. national identity). The textual metafunction deals with the creation of text, which as a whole constitutes genre e.g. a speech on the global economy. SFL views language as a resource for making meaning that resides in text.

As the conceptual framework is inspired by the transdisciplinary approach to language and globalization in contemporary society, this study refers to CDA which commits a dialogue between disciplines, i.e. critical linguistics, political economy and state theory. The scheme is centered by discourse as one moment of social material processes, realized ontologically in the current study in the form of concrete text. In other words, the scheme is centered by a social problem that has a semiotic aspect - discourse of global economy in turbulent times. The circles in the diagram represent disciplines and layers of analysis. The segments symbolize "dialogicality" (Fairclough, 2003, p. 42) and the dashed lines indicate that the analyst needs to cross the discipline by which the explanatory critique enables to oscillate from one discipline to another in analyzing texts on the global economy.

According to Fairclough (2003), to deal with the language-oriented social problem, one needs to refer to genre which is a way of interaction (e.g. political speech, Opinion-Editorial article), discourse which is a particular way of representation (e.g. new economic strategies), and style which is a way of being (e.g. state). The transdisciplinary 
approach is used to tackle the social order (social and material processes of global economic strategies). The transdisciplinarity is located in the oscillating process of analysis, between linguistics, political economy and state theory. This study refers to CDA because of the standpoint that global economic agenda is politically embedded in discourse and that both political and economic objects are socially constructed in discourse (Fairclough, 2006). In other words, discourse is constitutive and constituted. Consequently, the combination of critical linguistics, political economy and state theory allows the analysis of texts to be coherently integrated through a dialogue between theories that later provide resources for actualization of economic and political practices. The notion of transdisciplinary will be elaborated in the method section below.

The discursive representation of global economy is a complex social phenomenon. It is viewed to be crucially determined in constituting and internalizing the way we talk about the systems of government policy, state politic, and development and the way we look at other social realities. To theorize global economy as a facet of discourse, we draw from a dialectical view that guides to the standpoint that discourse and economic practices are internalized and internalize within other moments or practices (Fairclough \& Thomas, 2004). As a regulated system of talking and doing things, the social practice as treated in this article has various orientations-economic, political, and social—discourse may be embodied in all of these without any of them being reducible to discourse (Fairclough, 2003).

\section{Method}

\subsection{Analytical Framework}

The research method used to collect empirical materials and analyze the data in this article shares an important set of family resemblances with critical linguistics and political economic forms of research. The most suitable analytical framework as it has been described above is therefore critical discourse analysis (CDA) that sees discourse as a particular way of representation of the social world from a transdisciplinary standpoint. CDA in this article is used as an inclusive term to mean a critical framework for doing research and a research method as well. This allows the analysis to oscillate between the two main paradigms of explanatory critique i.e. critical reading on "social structures" (Fairclough, 2003, pp. 16-17; Fairclough, 2010, p. 172) which is part of linguistics and critical social analysis on "strategies of social agents" (Fairclough, 2003, pp. 22-23), which is part of political economy. The analytical framework also seeks to include state policy analysis, which is part of state theory. As set out in the scheme above, the system of analysis of discourse applied in this article, appositely, is transdisciplinary. It involves linguistics (Fairclough, 2003), cultural political economy (Jessop, 2004; Hahnel, 2015), and theory of state (Jessop, 2002). Thus, we need a transdisciplinary analysis for examining "the workings of language in new economy society" (Fairclough, 2010, p. 1, italic mine) as the focus of inquiry.

The analytical framework is based on CDA insights that treat discourse as semiotic (language), the inter-subjectivity production of meaning, as an irreducible element of all material social processes. We can see social life as interconnected networks of social practices of diverse sorts - economic, political, cultural etc. (Fairclough, 2003). This study regards discourse of globalization as a practice within social life consisting of three interrelated dimensions: genre (practice of interaction), discourse (practice of representation) and style (practice of constituting identity). This paradigm of exploration allows the analyst to investigate the two types of genre both through textually oriented analysis and through a social explanation. This is because CDA views language as a form of social practice, which both constitutes the social world and is constituted by other social practices. The analysis can focus on (1) the linguistic aspects of the text (the concrete ontological form); (2) processing relating to the circulation of text (intertextuality and interdiscursivity); and (3) the wider social practice which the text politically concerns and to which the communicative event belongs. This article is based on the first and third dimensions. The analysis will focus on the propositional content and linguistic features of texts which include: evaluation in texts and value assumptions; argumentation, presupposition and implications; process types, representation of social agents and their actions; vocabulary, choices of vocabulary, the meaning of key words and patterns of collocation.

\subsection{Sources of Data}

This article focuses on economic texts which are specifically concerned with political economic issues, state policies and strategies in the time of financial meltdown and the ways they are embedded in such genres as political economic speeches. The texts come from the United States as the world's first largest economy and China as the second largest one. References will be made to a particular source of text, that is, one Op-Ed article and four speeches that are related to the global economy in turbulent times. These texts are produced by influential figures - heads of state - and circulated by governmental institutions and mass media. The texts deal with the state's new economic agendas and interests to cope with the meltdown. These texts are strategic genre, not because they disseminate information to the global society but because their contents are decisive in shaping the government's economic policy/strategy and concerned with both the inculcation of ideology and agendas of political economy (Ar, 2015; Fairclough, 2003). In 
other words, the texts constitute a means of communicative action that attempts to influence and create mutual understanding rather than merely disperse information. The consumers of these texts are influential figures too, including leaders of state, members of the parliament and central bank governors who are certainly concerned with the global economic crisis.

For the China context, the texts were originally in Chinese. This article nevertheless uses the English versions. As they were authoritatively prepared by the government of China, the texts still belong to the discourse of China's economy. The texts for the sources of data are set out in the table below.

Table 1. The texts for sources of data on global economic strategies in turbulent times

\begin{tabular}{|c|c|c|c|}
\hline Date & Author & Title & Word count \\
\hline Oct 17,2008 & $\begin{array}{l}\text { Gordon Brown, } \\
\text { Washington Post }\end{array}$ & Out of the Ashes & 705 \\
\hline Nov 13, 2008 & George Bush & Financial Markets and World Economy & 2,955 \\
\hline Sept 13,2010 & Wen Jiabao & $\begin{array}{l}\text { Consolidate the Upward Momentum and } \\
\text { Promote Sustained Growth }\end{array}$ & 3,246 \\
\hline Jan 21, 2011 & Barrack Obama & Competing in the Global Economy & 2,325 \\
\hline Sept 14, 2011 & Wen Jiabao & $\begin{array}{l}\text { Promote Sound, Sustainable and Quality } \\
\text { Development }\end{array}$ & 2,821 \\
\hline Total word count & & & 12,052 \\
\hline
\end{tabular}

The analysis in this article is labor-intensive and very much qualitative work. Consequently, I will be able to analyze only a limited number of excerpts. The analysis of the fragments purposely represents the 12,052 word corpus, which knowingly leads to a topic-based exploration. As a common analytical convention, paragraphs are marked by (para. 0). Omissions are marked by (...)

\section{Data Analysis and Discussion}

In this section, I shall present the data in the form of extracts and provide a discussion for them. As a common practice in CDA, the discussion is always interspersed with text excerpts as data. The exploration of global economic issues in this article relies on a topic-based analysis. As has been described in the Introduction, this study assumes that there are strategies in the form of precepts that the state leaders consider highly desirable during the global economic recession. Among the important strategies are: reform the global economic system, maintain flows of capital and investment, and sustain competition in the global market. I shall discuss each of these major characteristics of the current global economy in turn.

\subsection{Reform the Global Economic System}

Reform is one of the essential strategies in the practices of global economy in turbulent times. The discursive practice of the current economy focuses on rescaling from local, national to global and restructuring the economy and politic. The notion of flexibility in defining space and time is conceived as a crucial feature in the economic downturn. The extracts below provide illustrations:

[1] The old postwar international financial institutions are out of date. They have to be rebuilt for a wholly new era in which there is global, not national, competition and open, not closed, economies (para. 5). (...)

We have to tackle the root causes. So the next stage is to rebuild our fractured international financial system (para. 7). (...)

To do this, we need cross-border supervision of financial institutions (para. 8). (. .)

Tomorrow, French President Nicolas Sarkozy and European Commission President José Manuel Barroso will meet with President Bush to discuss the urgent reforms of the international financial system (. . .). The reforms I have outlined are vital to ensuring that globalization works not just for some but for all hard-pressed families and businesses in all our communities (para. 9).

Over the past week, we have shown that with political will it is possible to agree on a global multibillion-dollar package to recapitalize our banks across many continents. In the next few weeks, we need to show the same resolve and spirit of cooperation to create the rules for our new global economy (para. 11). (Gordon Brown, Washington Post, October 17, 2008) 
[2] The leaders attending this weekend's meeting agree on a clear purpose - to address the current crisis, and to lay the foundation for reforms that will help prevent a similar crisis in the future (para. 5). (. . )

In addition to addressing the current crisis, we will also need to make broader reforms to strengthen the global economy over the long term. This weekend, leaders will establish principles for adapting our financial systems to the realities of the 21 st century marketplace (para. 17). (...)

One vital principle of reform is that our nations must make our financial markets more transparent. For example, we should consider improving accounting rules for securities, so that investors around the world can understand the true value of the assets they purchase (para. 18).

Fourth, we must strengthen cooperation among the world's financial authorities. For example, leading nations should better coordinate national laws and regulations. We should also reform international financial institutions such as the IMF and the World Bank, which are based largely on the economic order of 1944. To better reflect the realities of today's global economy, both the IMF and World Bank should modernize their governance structures (para. 21). (George Bush, November 13, 2008)

[3] We will deepen reform and increase the dynamism and vitality for sustainable development. China's development and progress would not have been possible without reform and opening-up. And to achieve the modernization goal of building a prosperous, democratic, culturally-advanced and harmonious country, we still need to rely on reform and opening-up. (...) We must deepen comprehensive reforms in the economic, political and other fields to enable the entire system to better meet the needs of developing a modern economy and building socialist democracy, push forward social equity and justice and facilitate the free and all-round development of the people (para. 12). (Wen Jiabao, September 13, 2010)

[4] We have taken an active part in the reform of the global economic governance structure and the building of regional cooperation mechanisms, and worked to deepen bilateral and multilateral economic and trade relations. China today is a fully open market economy. The opening-up policy has both benefited China's development and the well-being of its people and contributed to regional and global economic growth (para. 6). (...)

We will continue to advance both economic and political structural reform to create strong impetus for economic and social development (para. 14). (Wen Jiabao, September 14, 2011)

The extracts indicate that reform is conceived as the crucial strategy in tackling the global economy in turbulent times. Being able to define critically and implement the concept of time and space: past vs. today, national vs. global, closed vs. open is absolutely necessary. The processes of rebuilding, rescaling, and reforming are not predetermined, not naturally given, but socially constructed (Fairclough, 2006). For example, the discourse of national economy is rescaled from China to global. Thus, there is now a need for reform of 'the global economic governance structure' [4].

Time and space is emphasized as in a 'wholly new era' the economy is not 'national' but 'global'; hence the global economy is articulated to include worldwide, 'China's development . . . regional and global economic growth' or being rescaled 'across many continents' [1], by deepening 'bilateral and multilateral economic and trade relations' [4]. Modifying adjective 'global, not national' [1] entails that the global economy is in crisis and thus it needs to be 'rebuilt' and rescaled. Since rescaling economies is a political exercise, the process involves human agents 'we' as in 'we need cross-border supervision' [1], 'we have shown ...', 'we will also need to make broader reforms to strengthen the global economy over the long term' and 'We should also reform international financial institutions ... ' [2] and 'we must deepen comprehensive reforms ...' [4]. The unsaid here is that despite rescaling, there exists dominance even during the financial turmoil. The control is in the form of trade liberalization in which the United States, Western Europe, Japan and now China lead the global economy. The control is also in the form of new 'rules for our new global economy' such as international financial supervision. But these rules are mainly supervised by 'leading nations', notably the United States and UK through the Bretton Woods institutions - the IMF, the World Bank and the WTO.

As a smart emerging-economy country, China represented by its leaders strategically maneuvers by taking part in the global economy through the reform and opening-up policy [3]. The policy provides China with a safe haven to bow politically to the dominant U.S. and European paradigm of the global economy and at the same time prioritizing national interests. In fact, such discursive practice is no more than lip service - an intelligent attempt to maintain a status quo by the metaphor of 'opening-up' and 'reform'. This statement seems pejorative, but it can be true because the discursive representation of global economy does not seem to abandon the national interests, goals and motives of an engaging country. China's reform includes restructuring state-owned enterprises, promoting exports and improving the investment climate. The verbal process 'will continue' [4] presupposes that China has already reformed its economic policy. Since it started deregulating its economy in 1978, China has transformed itself from the proletariat economy into state capitalism. It is moving from the socialist to a full market-based economy system. 
Restructuring the economic practices is part of reform. It aims at changing the ways a country operates its economic policies and strategies in reorganizing enterprises for the long-term development. The extracts below provide us with some typical examples:

[5] We are seizing the opportunity to push ahead comprehensive industrial restructuring and upgrading. In tackling the international financial crisis, we have always given top priority to transforming the economic development pattern and restructuring the economy. In the past two years, domestic demand, consumption in particular, has played an increasingly strong role in driving economic growth. (. . .) What is more important is that we have made all-round arrangements for accelerating the transformation of economic development pattern and economic restructuring from a macro and strategic perspective (para. 3). (...)

We need to take into consideration both the immediate needs and long-term development and, while continuing to energize the recovery, create conditions for sustainable development through structural reform. This is a common task for all countries (para. 7). (...)

We must deepen comprehensive reforms in the economic, political and other fields to enable the entire system to better meet the needs of developing a modern economy and building socialist democracy, push forward social equity and justice and facilitate the free and all-round development of the people (para. 12). (Wen Jiabao, September 13, 2010)

The main argument in the extracts is that restructuring the global economic development is essential in turbulent times. Restructuring is textually constructed as 'top priority' which includes 'transforming the economic development pattern' from small to a large scale and from micro to 'a macro and strategic perspective' which is politically seen as a 'common task for all countries.' The process of restructuring enables a globalizing country to increase domestic demands that plays a crucial role in driving the economic growth in the short term. It also facilitates a country's economic growth in the long run. Restructuring is taken for granted as a strategic momentum in the processes of global economy. Restructuring and rescaling are internalized through a contextualized movement from the economy to the politic, from 'closed' to 'open' and from local, regional, national to global. Restructuring is a dialectical process. Economy and politic constitute each other. Both rescaling and restructuring economic practices involve human participants 'we' as in 'we will continue to advance both economic and political structural reform [4] and nations as in 'for all countries' [5]; hence, the interface between economy and politic is inevitable in the age of global economy. The inexorableness in the global economy brings about a ruling dominance with an imperialist register. Heron $(2008$, p. 86) point outs that globalization is "intricately tied up with the forces of imperialism and is essentially, not really new in form, but rather new in the nature of its manifestations of domination." This domination is not only discursively constructed in texts but also practiced in global social life.

Reform also includes reaffirming the deregulation of economy. It is the process that removes distortions caused by regulations or the presence of government. The term deregulation can be used interchangeably with 'opening', a name for similar policies to promote neoliberal free-trade economies. Supporters of neoliberalism such as the WTO believe that removal of regulations encourages the efficiency of a market by raising competitiveness and ultimately lowering prices - especially wages. Deregulation of the economic practices has been a major trend in Britain, the United States, and Japan. These practices are supported by the international institutions like the OECD, the IMF, and the WTO.

State leaders of the producing countries advocate the reduction of 'government intervention' in the economy. Even in the turbulent times, they still argue that market should be 'free from the intervention of government' because 'a fully open market economy' not only benefits a producing country but also contribute to 'global economic growth'. The extracts below (partly reused) provide a picture of deregulation of the economy:

[6] All these steps require decisive actions from governments around the world. At the same time, we must recognize that government intervention is not a cure-all. For example, some blame the crisis on insufficient regulation of the American mortgage market. But many European countries had much more extensive regulations, and still experienced problems almost identical to our own (para. 23). (. . .)

History has shown that the greater threat to economic prosperity is not too little government involvement in the market, it is too much government involvement in the market (para. 24). (. . .)

When nations open their markets to trade and investment, their businesses and farmers and workers find new buyers for their products. (. . .) Thanks in large part to open markets, the volume of global trade today is nearly 30 times greater than it was six decades ago-and some of the most dramatic gains have come in the developing world (para. 32). (...)

Stories like these show why it is so important to keep markets open to trade and investment. This openness is especially urgent during times of economic strain (para. 34). (...) 
There are clear-cut ways for nations to demonstrate the commitment to open markets (para. 35). (George Bush, November 13, 2008)

[7] The first decade of this century has seen major changes in the global political and economic landscape. It has also seen rapid industrialization and urbanization in China. Great progress has been made in China's comprehensive reform, opening-up and modernization endeavor during this decade (para. 3). (. .)

We are pursuing a win-win strategy of opening-up to increase the openness of China's economy. Since joining the WTO in 2001, we have speeded up efforts to change the way of conducting foreign trade, improved the import and export mix, upgraded the processing trade and vigorously developed trade in services. (. . .) China today is a fully open market economy. The opening-up policy has both benefited China's development and the well-being of its people and contributed to regional and global economic growth (para. 6). (...)

China will continue to deepen reform and opening-up and resolutely remove institutional hurdles to increase the momentum of pursuing sustainable development (para. 14). (Wen Jiabao, September 14, 2011)

Deregulation of the market is textually manifested by the economic strategy frequently referred to as 'opening-up'. The lexical choice 'open' seems to be the euphemism of 'global'. As the economy is part of social life, it is an open system. Therefore, ontologically the 'openness' stance is constructed through the lexical item 'open' or 'opening-up'. As euphemism, the word 'open' perhaps has a less provocative meaning compared to the word 'global' per se; it is used in other social contexts such as education-open university. A university that is open welcomes every person but sounds less competitive. The word 'open' also suggests that there should be no secret agenda from a special state in the global economy. In other words, there must be accountability, 'transparency', and trusted governance between countries. Simultaneously, lexical 'open' indicate the value of liberalizing economic practices, that is, open in competition. From a SFL perspective, the lexical choice 'open' can be used as a verbal group as in 'When nations open their markets' [6] and therefore it can co-occur with an inanimate colligate subject 'nations' and its predicate collocations include 'market', 'trade' and 'investment'. However, the word is used as adjective as in 'open markets', 'open economies', 'open multilateral trading regime'. Whether it is used as a main verb or modifying adjective, in the economic texts the word 'open' is part of language that embodies neoliberal free market.

In [6] the government action in the economy is decisive and the intervention is denounced despite the fact that in July 2008 to save the economy "the US government poured \$200 billion into Fannie Mae and Freddie Mac, the mortgage lenders, and nationalized them" (Chang, 2011, p. 8). State involvement functions as an essential salvage only when the economy is on the verge of collapse. That is how the capitalist system of economy operates. In [7] the nonfinite clause 'Since joining the WTO in 2001 ' presupposes that the WTO is an economic institution that endorses free trade. It is not the government but the WTO that is the player, acting as the economic social actor in legitimizing free trade. Its deregulation of trade lessens the state's function in controlling the economy. The WTO, formed on January 1, 1995, as a successor of the General Agreement on Tariffs and Trade (GATT) in the Uruguay Round Agreements now with 134 member countries, is committed to the global free trade through the reduction and removal of 'tariffs', 'barriers', and 'institutional hurdles' from trade. Back in 1994, GATT Director General Peter Sutherland said "Governments should interfere in the conduct of trade as little as possible" (speech on the U.S. approval of WTO in New York on March 3, 1994).

The powerful WTO and other international trade agreements, such as the North American Free Trade Agreements have approved global competition and unregulated market as the best opportunity to create the equal prosperity of the world's population. This new governing regime increasingly provides a major general control over every aspect of the lives of the majority of the world's people. Unfortunately, the control is not for the economic well-being of nations as the claim is often made but rather on the enhancement of the power and wealth of the world's largest corporations and financial institutions. The WTO's agreements is committed to global free trade providing opportunities for multinational corporations as a resource for accumulation of wealth without taking into account the devastating consequences of free trade practices on environment. Some advocates pretend to have considered the issue by manufacturing consent that "freer trade appears to be good for the environment" (Antweiler, Copeland \& Taylor, 2001, p. 877).

The Bretton Woods agencies, the World Bank, the IMF and particularly the WTO sanctify the intellectual property rights (IPRs) as an economic operational tenet and the state leader approves it. The extracts below including reused illustrate:

[8] On 1 August 2008, the Beijing-Tianjin Intercity Railway, China's first top-class high-speed rail with full intellectual property, was put into operation, shortening the travel time between Beijing and Tianjin to only 30 minutes and binding the two major municipalities as one (para. 3). (. . )

We will upgrade the traditional industries with advanced technologies, nurture a number of internationally competitive enterprises with their own intellectual property and well-known brands, and build a number of 
world-class modern industry clusters which can serve as growth drivers, so that China can move industry clusters which can serve as growth drivers, so that China can move from a big manufacturing country to a strong manufacturing country (para. 9). (...)

China's development is open development. China's opening-up is long-term, comprehensive and mutually beneficial. We will uphold all policies conductive to opening-up. China is committed to creating an open and fair environment for foreign invested enterprises. China gives high priority to intellectual property protection and has already made this a national strategy (para. 13). (Wen Jiabao, September 13, 2010)

[9] We will enhance capacity to create, utilize, protect and manage intellectual property rights and bring into play the creativity of the whole society (para. 11). (Wen Jiabao, September 14, 2011)

The crucial value of the free-market system is the attempt to deregulate trade and fully justify the property rights of individuals and 'enterprises'. The argument in the extracts implies that the IPRs are not entirely secure in China but they are a reward for those who are hardworking and capable of competition. The IPRs refer to the intangible property resulting from inventive activity. They control two broadly categorized groups of ownership: industrial property and copyrights. The former includes industrial designs 'China's first top-class high-speed rail' and trademarks for brand identity 'well-known brands'. The latter refers to works such as paintings and music. The term in academia is now appropriated to suit economic discourse. Thus, IPRs need to be 'utilized', 'protected' and has become 'a national strategy'. This indicates that market is practiced based on the principle of laissez-faire (letting the economy do what it wants, self-regulating) in which governments should stay out of economic matters because corporations (the invisible hands) know the market better than the government. This policy is part of the characteristic of neoliberal economy, a political project that aims at facilitating the restructuring and rescaling of relations across social fields (economic, politic, and social) and spaces (national, regional, and global). This is a notorious social change of the contemporary global society (Fairclough, 2003). The change of market systems brought about radical attacks (e.g. riots and looting in Britain in August, 2011) by the affected groups of people who used to live with support from the state. These people contend that the neoliberal controlled economy creates a wider division between the rich and poor.

The most severe consequences of deregulation are not from trade liberalization but from liberalization of the capital or financial markets. Financial deregulation, for example, allows banks and corporations to borrow abroad and invest without any government controls or coordination and without sufficient bank supervision. When connected by communication technology used in the international monetary system, speed of the process of capital transaction can be increased globally. For example, persuaded by the IMF and western governments, Asian governments agreed on radical financial deregulation in 1990s which ultimately led to the 1997 Asian financial crisis. Thanks to small and medium-size enterprises, Asian countries, for example Malaysia and Indonesia survived from the crisis.

Trade deregulation, without doubt, benefits importing and exporting services and not people at large. The goods imported into a country cannot become cheap only because there is no tariff or taxes. Brokers or distributors are always in pursuit of high profits. Deregulation of market can work properly if the economy is under state's control and is managed by wise leaders, who are scarcely found in modern times and let alone in the competitive and individualistic society. Riots in many parts of globe in mid and late 2011 indicated that the current economic form of globalization needs a paradigm shift. Otherwise, conflict of interests can prompt the bigger crises, such as global financial turmoil and currency war. The unfair practices of global economy have led to opposition of capitalist economic ideology (e.g. Wall Street Occupy Movement in October of 2011) that was unable to control the liberalized economic system that is susceptible to recession due to "capital hunger". For that reason, the ideological manifestation that major economic countries like the United States and China galvanize in constructing the discourse of global economy is the emergence of obviously inevitable impacts of free market on the global economy that has led to the international financial crisis and national instable currencies. The globalist often speak of 'free-market economy' in the name of democracy without thinking that a too free economy destroys democracy.

\subsection{Maintain Flows of Capital and Investment}

Maintaining flows of capital and investment constitutes another desirable economic strategy that the globalists keep promoting in turbulent times and it is assured as part of the social material processes of globalization. Capital and investment act as resources for global economic development that need to be open, moved and increased. The extracts below (partly repeated) illustrate:

[10] The old postwar international financial institutions are out of date. They have to be rebuilt for a wholly new era in which there is global, not national, competition and open, not closed, economies. International flows of capital are so big they can overwhelm individual governments. And trust, the most precious asset of all, has been eroded (para. $5)$. 
When President Bush met with the Group of Seven finance ministers last weekend, they agreed that we all had to deal with not only the issue of liquidity in the banking system but also the capitalization and funding of banks. It was clear that national action alone would not have been sufficient (para. 6). (...)

Over the past week, we have shown that with political will it is possible to agree on a global multibillion-dollar package to recapitalize our banks across many continents (para. 11). (Gordon Brown, Washington Post, October 17, 2008)

[11] This is a city whose capital markets have attracted investments from around the world and financed the dreams of entrepreneurs all across America. This is a city that has been and will always be the financial capital of the world (para. 2). (George Bush, November 13, 2008)

[12] We have pursued the dual strategy of introducing foreign capital and encouraging Chinese companies to invest overseas to achieve greater balance between the use of FDI and overseas Chinese investment (para. 6). (. . .)

China will continue to develop education as a priority, bring about all-round human development, and promote economic development on the basis of improving the quality of human capital. For a major developing country like China, boosting education and improving quality of human resources will drive economic development and make it more competitive. We will act quickly to achieve economic growth by increasing the quality of human capital rather than by just using more workers (para. 10). (...)

We will continue to improve foreign-related economic laws, regulations and policies so as to make China's investment environment in keeping with international standard, transparent and more business friendly (para. 15). (Wen Jiabao, September 14, 2011)

Capital refers to a form of economic resources. It can refer to man-made materials, financial wealth, means of production and distribution as well as labor, often called 'human capital'. The extracts demonstrate that capital involved generally includes: financial wealth 'international flows of capital', 'foreign capital'; means of distribution 'capital markets'; and human resources 'the quality of human capital'. The issues of the 'quality of human capital' and 'transparency' matter for the global economy in recession. It is presupposed that capital is transferable from one place to another, hence 'flows of capital'. This movement of capital is economically global as in 'international flows of capital'. But the movement of capital is socially and politically constructed. The invisible hands do the job, hence, 'the capitalization and funding of banks' (self-process entity), 'to recapitalize our banks across many continents' (active nonfinite verb without overt agency), and 'a city whose capital markets . . . a city that has been ...' (personification of space).

The 'flows of capital' [10] means the transfer of money abroad; thus they are 'international'. They attract investors and governments, but they can sometimes erode trust between governments as represented in [1] above. Capital must keep flowing in turbulent times. Capital needs circulation to provide the owners of the means of production with a surplus they can extract as profits. It can be short, medium or long term but all have some effect on the exchange rate because money entering or leaving a country has to be converted from one form of currency to another. Medium- or long-term capital flows are considered less troublesome because they have less dramatic effect on the exchange rates and often associated with investment. As a result, they 'can overwhelm individual governments'. In contrast, short-term capital flows can be speculated for profit generated by interest-rate levels. A rapid growth of short-term flows can also lead to the increased instability of financial markets, such as the late 1990s East Asia crisis and the U.S. led 2008 global financial chaos. When the crisis occurs, governments must 'recapitalize banks'. This is because capital flows are the life blood of the capitalist system. The system sometimes weakens, gets interrupted and enters crisis. Then it alters again; hence, the enigma of capitalism is a vicious circle. This system of political economy can be transformed, for example, from old capitalism (ownership of land, factories) to new capitalism (financial market, technological information, knowledge). Most important of all, the system offers people 'freedom'. People who endorse capitalism can do what they want and run any business they like; it provides them with dignity and profit because of competitive hard work. Profits in capitalist economy are perceived as a reward for those who are capable of competition. One way to get financial rewards is through investment.

Extracts [11] \& [12] indicate that 'investment' like capital can move from one country to another called 'foreign direct investment' or 'FDI'. The word and its derivatives can collocate with a number of words including 'foreign', 'fixed' (adjectives), 'environment', 'overseas', 'utilization' (nominal groups), and 'make', 'use', 'attract' (verbal groups). The adjectival words are politically concerned with source or condition. The nominal groups are concerned with political economy; meanwhile the verbal groups that the word accompanies are grammatically to do with material process verbs. The grammatical colligation of 'investment' is geographical spaces, for example, 'a city', 'the world', 'America', and 'China'. The extracts show that investment has become an essential concept in the discourse of global economy in turbulent times. Politically, investment has become one of the many different things that need to be globalized. Therefore, 
its contribution to globalization gains is discursively indisputable. The potential object of investment is 'capital' or money that provides investors with higher returns. As used in [11] \& [12], investment seems to signify brownfield investment, that is, acquisition of local firms by a foreign company rather than greenfield investment, establishing new firms that will provide training for labor force; this is because training the new labor force is less profitable. Even though improving 'the quality of human capital' is a priority, it is only for making the economy 'more competitive'. Taken together, the United States and China have liberalized capital and investment, but no mention is made that the countries have also liberalized labor. The aim of argument in the extracts is to win the state leader and investor approval of a reshaped global economic strategy in turbulent times, not to promote labor rights.

Conceptually every country is encouraged to develop, equal growth of the world, for example through FDI. But in reality, investment tends to move into its favored locations. Consequently, investment is more difficult to negotiate for some economies. This is one side effect of unequal globalization. The main objective of the global economy is to boost equal growth for mankind, i.e. a process of global social changes. However, capitalists do not throw a dice when they invest their money. They are selective. They choose the most promising location. The imprudent state of affairs is that capitalists now invest more in financial markets than in productive economic activities. Capital also has a nationality. The profits accumulated from investment go to the home countries of investors. But this policy is not articulated in the texts. Furthermore, capital investments are concentrated in the developed world and in a few developing countries. In recent years, China as the world's second largest economy has become the most preferable. China has become an easy target for investment because foreign investors generally aim to take advantage of cheaper labor. Many other Asian countries such as Cambodia and Bangladesh are neglected. This happens because there is an alleged lack of infrastructure, facilities and skilled labors in these countries or because of the small market that exists there. The majority of developing countries still allocate more finances from their fiscal budget for social welfare, food sustainability, clean water and sanitation. As a result, they are unable to build better roads, industrial ports, and airports to attract FDI.

The undesirable consequences of the free movement of capital and investment hurt neglected countries. For example, as lack of FDI is suffered by countries of the "Third World", marginalization and inequality are unavoidable. This could be the case because "investment does not flow from the areas of capital abundance to the locations where capital is relatively scarce. Instead, it tends to concentrate in favoured locations" (Kiely, 2000, p.1066). North America, Western Europe, Japan, and China are among the most favored; less developed Central America, South Asia, and sub-Saharan Africa as well as small states are marginalized (Bora, Razzaque \& Grynberg, 2004; Lee \& Smith, 2010). Indeed, the flows of wealth to the "Third World" have declined for hundreds of years and created inequality of investment opportunities for less developed countries (Milanovic, 2016). Marginalization does not always mean low quantities of investments but it also means low quality. That is, companies invest in the locations where 'human capital' is cheap. This is partly in line with globalization from the Washington consensus onwards that was directed at freeing the movement of capital and labor so that businesses could find the cheapest labor force in the most convenient locations. For the sake of the overall-targeted development of humankind, the alternative globalization - the one that emerges from "below" must be compelled — by empowering the labor and labor providing countries.

Investment can boost the economic growth if it is equally distributed. However, in the real practices, investors tend to concentrate in promising locations with a large profit. Countries that have large market for goods and services but with lower cost of productions will attract investment most. On the other hand, countries that provide small market do not attract capital investment. Ultimately, to reduce poverty as one objective of globalization remains merely a claim that is discursively constructed. The claim is getting more difficult to prove when the current global economic growth is sluggish and heavily dependent on stiff competition. This is the topic to which we now turn.

\subsection{Sustain Competition in the Global Market}

Competition is not a new thing in the economy. The value of stiff competition in the global marketplace is inculcated in the discursive construction of global economy in turbulent times. This strategy is highly desirable and motivated by the notion that economic activities in this modern age are regarded successful if nations are capable of high competition. Competition stands hand in hand with the concept of opening-up discussed above. The following extracts partly reused provide examples of the concept of competition as a strategy of practicing the global economy in turbulent times:

[13] The old postwar international financial institutions are out of date. They have to be rebuilt for a wholly new era in which there is global, not national, competition and open, not closed, economies (para. 5). (Gordon Brown, Washington Post, October 17, 2008)

[14] We've seen our economy transformed by rising competition from around the globe (para. 5). (...)

So we know we can compete. Not just in the industries of the past, but also in the industries of the future (para. 12). $(\ldots)$ 
For America to compete around the world, we need to export more goods around the world. That's where the customers are. It's that simple (para. 13). (...)

During those meetings, we struck a deal to open Chinese markets to our products. They're selling here, and that's fine. But we want to sell there (para. 16). (. . .)

Now, nobody understands this better than Jeff Immelt. He understands what it takes for America to compete in the global economy. As he mentioned, I've appreciated his wisdom during these past two years. We had a difficult, difficult crisis on our hands (para. 22). (. . .)

The past two years were about pulling our economy back from the brink. The next two years, our job now, is putting our economy into overdrive. Our job is to do everything we can to ensure that businesses can take root and folks can find good jobs and America is leading the global competition that will determine our success in the 21 st century (para. 28). (...)

So ultimately winning this global competition comes down to living up to the promise of places like this (General Electric) (para. 34). (Barrack Obama, January 21, 2011)

The common definition of lexical item 'competition' is a situation in which two or more people or groups are trying to get something which one person or group can have. Competition is also an activity involving two or more firms in which each firm tries to get people to buy its goods in preference to the other firm's goods. These two definitions of 'competition' inform us that competition is a condition in the first definition and an activity in the second that involves two or more people or firms. Conceptually, these definitions are self-evident. In the discourse of global economy, however, the word is used in terms of winning, not losing. Competition is also taken for granted in achieving a nation's economic successes. The fact that a strong competition does not always lead to fair free trade but to monopolistic market controlled by world giants is not represented in the texts.

Competition is a contested economic component even in the face of recession. The extracts indicate that competition is economically global, hence 'the global competition' and 'this global competition'. But at the same time, competition can be 'rising'. Most importantly competition needs to be won as in 'winning this global competition'. The agency or grammatical colligation of competition process is nations as in 'For America to compete around the world' and 'America is leading the global competition'. This argument presupposes that competition is not a win-win economic activity, but an activity that creates market winners and losers. This is illustrated in the uses of argumentative indicator 'so' to conclude the points in [14]. After all, each nation is in pursuit of competitive advantage. Competition still amounts to a global economic strategy in the turbulent times since it supposedly keeps boosting growth of the global economy. This strategy is politically constructed by the dominant economies and their financial institutions. Like the flows of capital, competition is determined by market. Economic globalization provides opportunities for countries around the world to compete in the single global marketplace. But the reality is different from what the dominant globalists proclaim. Most of the economies are dominated by giant corporations. As a result, there is no fair competition in the global market. For instance, the Switzerland's patented trademark dairy products Nestlé reach the global market from the EU single market-destroying small local dairy companies and the livelihoods of poor farmers (GRAIN's report, December 7, 2011). Despite huge profits from the products, the corporation rarely takes part in helping reduce starvation in poor countries like Somalia and Ethiopia even though it sells the products there. In fact, Nestlé was even accused of having killed babies in those places (INFACT's report, 2004).

Despite the claim 'there is global, not national, competition' and 'open, not closed, economies', the course of history has shown that competition as a system of global market is, in the end, not always fair. This is because a strong trade competition very often brings about monopolistic market. Only those companies that manufacture mass productions will control the market. Ultimately, certain groups of people and firms control the global economy. Global economy of course does not exist without competitive trade. Countries are encouraged to compete in order to thrive and provide jobs for their people. The discursive character of this globalist strategy is illustrated in utterances 'we've seen our economy transformed by rising competition from around the globe' and 'America is leading the global competition', which shows that the United States is still eager to dominate the global economy by means of naturalizing competitiveness value in economic social affairs. Given the fact that not all companies particularly those located in the developing economies are giants, this desirable value needs to be transformed, so that local and national companies in those countries are able to participate in the global economy by cooperating with the giants, such as Silicon Valley and General Electric.

Competition in the globalized economy is seen as the engine of a new economic system. One way of economic competition in the global economy is to produce large amounts of goods and provide high quality services. The discourse of global economy encourages companies (e.g. Coca Cola, Nestlé, and Citibank) to manufacture special goods and services in order for them to compete. When the companies are producing large quantities of specific goods, the opportunity for them to compete is 'open' and as a result of that the competitive free trade becomes global. The 
worst consequence of it is that the practice of global economy brings about an unhealthy competition. That is, the social Darwinism of 'survival of the fittest' emerges. Small firms have to produce limited amount of goods and they have to raise the prices. For example, in Malaysia a global candy company can sell six pieces of chewing gum for only MY $\$ 1$ and still gets profit. Conversely, a similar small local firm must sell three pieces of chewing gum for MY\$1 in order to get profit. As a result, the local small firms attract only few consumers and ultimately they collapse. The practices of existing global capitalist economy give rise to perils not promises.

The most dangerous peril is monopoly. The competitive market has placed the nation state like the United States to hold the top position in the global hierarchy because of its capacity to compete in the global market. The United States and the G7 have attempted even to control worldwide financial markets in order to exercise the monopoly, using the U.S. dollar as one of the main currencies of transaction. More than that, the Unites States and its seven partners managed to establish the Bretton Woods institutions, the IMF, the World Bank and the WTO. But these institutions have not done much to facilitate development in developing countries. Instead, they prefer countries which are excellent competitors. The role of competition in the practices of global economy has made the social affairs, free trade, import and export vulnerable to oppression. At the beginning the process of competition is like a game of football. It normally runs smoothly, but in the long run it may turn to a real competition. This is because whether the game is held for friendship or for a trophy, the participants of each side are cognizant that the set target is to win the game. The same is true in a global marketplace. Although countries sign mutual trade agreements as stated in 'we struck a deal to open Chinese markets to our products' [14], each country endeavors to obtain the best opportunity. In other words, the countries engaged in the agreement always attempt to export more but import less. Accordingly, the discourse of export predominate the discourse of import in the economic texts. This suggests that it is the strongest producing country that will benefit most.

One can learn from 'They're selling here, and that's fine. But we want to sell there.' that the global economy involves exports and imports between countries. The triviality 'and that's fine' is pragmatically insincere. Politically, this is because the economic policies and politic of a country are the most determinant. At first, the reification of open competition in the global economy is manifested via discourse. Then the discursive practice moves to social reality, manifesting through productions-distributions and imports-exports. A country can win either at the discursive practice or in actual material processes or even both. Normally competition is of the same importance within the practices and within the hybridity of moments of economy and politic. As the two practices have a dialectical relationship, those countries that control the discursive practice also dominate the actual material processes. Although an open competition plays a guiding role in the global economy, it does not seem to support the globalist statement that globalization benefits everyone. The global economic project definitely benefits some countries and simultaneously it does hurt others. For instance, the U.S. market once rejected China-made children toys because the American authority considered them to be unsafe. This rejection indicates that economic cooperation is unable to escape exclusionism. The actual fact is that China is able to produce cheap and low quality industrial goods and products because of labor surplus.

Now eight years have passed since the 2008 failure of financial system, but none of the economic strategies discussed above has proved to be effective. The discursive practices of solutions to the global economic crisis have yet significantly contributed to the manifestation of material processes of the economic practices. The global economy is still sluggish; it is on the back of economic fragility in advanced countries and moderately moving in developing countries. In the United States the economic growth is generally supported by consumption but weak exports. In Europe the economy is bolstered by stronger domestic demand but low inflation. In China the slow economic growth persists and has changed from investment driven growth to consumption driven. Other emerging market countries still suffer stagflation with low economic growth and high inflation. In addition, the gap between the rich and poor is getting more widening even in the developed countries. The world financial institutions, the IMF and the World Bank, have yet offered better solutions to the crisis.

\section{Conclusion}

This paper has addressed the discursive construction of global economic strategies during the financial-economic downturn from state leaders' perspectives. Using CDA as an interdisciplinary, explanatory critique, the paper has identified a number of essential economic strategies highlighted in the discourse of global economy in turbulent times. The strategies include reforming the global economic system, maintaining flows of capital and investment, and sustaining competition in the global market. Generally, these neoliberal economic strategies were textually embedded in value assumptions, argumentation, and lexical choices.

The state leaders argued that reform was still part of the social material processes of global economic practices in turbulent times. Structural reform and retrenchment of the state regulation in the socio-economic sphere was significant for sustaining global development. Although it was the state that finally saved the economy through bailout, state 
intervention was undermined during the crisis. The discourse of 'opening-up', 'restructuring', 'reforming', and 'rebuilding' a free-market economy represents state leaders' sustainable belief in the new capitalist global economy. In the period of the crisis, the state leaders still advocate the practices of neoliberal economy without considering that the deregulation of trade benefits importing and exporting corporations, not the general public since goods keep getting more expensive for the majority of people. Reduction of tariffs and taxes are not sufficient conditions for making things easy to get and cheap. Importers and distributors are always in search of high profits. Economic activities will work properly and benefit all layers of society if the economy is under a wise control of the government.

The analysis identifies capital movements in the form of 'international flows of capital', 'foreign capital', and 'overseas investment' as an economic strategy in the era of global economic recession. This strategy is also represented through other lexical resources: 'capital markets', 'recapitalization', 'recapitalize', 'use of FDI' with syntactically concealed human responsibility. The issues that free capital movements increase the global economic growth were highlighted. In real practices, however, investors tend to concentrate in certain countries in which they can get higher returns. Countries that have large market but lower cost of productions attract investment most. On the other hand, countries that provide small market do not attract investment. Therefore, provision of well-being for all humankind as an objective of economic globalization remains as a discursive practice.

The analysis also reveals that competition is regarded an important strategy in the practice of global economy in turbulent times. The item 'competition' and its derivatives are employed to promote this strategy as to adapt a change of the old global economy to new era. The state leaders emphasize that nations need to compete globally to attain success. In practice, however, strong competition does not always lead to fair free trade but to monopolistic market controlled by giant corporations. This drawback of the free-market economy was not articulated in the texts. The proponents of free-market ideology claim that globalization allows for a healthy, competitive global economy. But real competition brings about dominance of selected corporations, particular groupings, powerful states, and regionalization instead of economic globalization.

\section{References}

Antweiler, W., Copeland, B. R., \& Taylor, M. S. (2001). Is free trade good for the environment? American Economic Review, 91(4), 877-908. http://dx.doi.org/10.1257/aer.91.4.877

Ar, M. (2015). Language and globalization: A critical analysis of global economy in strategic texts during the financial crisis. English Linguistics Research, 4(2), 1-16. http://dx.doi.org/10.5430/elr.v4n2p1

Bhaskar, R. (1986). Scientific realism and human emancipation. London: Verso.

Bora, B., Razzaque, M. A., \& Grynberg, R. (2004). Marginalization of LDCs and small vulnerable states in world trade. London: Commonwealth Secretariat.

Chang, H. J. (2011). 23 Things they don't tell you about capitalism. London: Penguin Books.

Chouliaraki, L., \& Fairclough, N. (1999). Discourse in late modernity: Rethinking critical discourse analysis. Edinburgh: Edinburgh University Press.

Crotty, J. (2009). Structural causes of the global financial crisis: A critical assessment of the 'new financial architecture'. Cambridge Journal of Economics, 33, 563-580. http://dx.doi.org/10.1093/cje/bep023

DeVille, F., \& Orbie, J. (2014). The European commission's neoliberal trade discourse since the crisis: Legitimizing continuity through subtle discursive change. The British Journal of Politics \& International Relations, 16(1), 149-167. http://dx.doi.org/10.1111/1467-856X.12022

Fairclough, I. \& Fairclough, N. (2011). Practical reasoning in political discourse: The UK government's response to the economic crisis in the 2008 pre-budget report. Discourse \& Society, 22(3), 243-268. http://dx.doi.org/10.1177/0957926510395439

Fairclough, N. (2003). Analysing discourse: Textual analysis for social research. London: Routledge.

Fairclough, N. (2006). Language and globalization. London: Routledge.

Fairclough, N. (2010). Critical discourse analysis: The critical study of language (2nd ed.). London: Longman.

Fairclough, N., \& Thomas, P. (2004). Discourse of globalization and globalization of discourse. In D. Grant (Ed.), London: Sage.The Sage handbook of organizational discourse, 380-396.

Hahnel, R. (2015). The ABCs political economy: A modern approach (2nd ed.). London: Pluto Press.

Halliday, M. A. K., \& Matthiessen, C. M. I. M. (2014). Halliday's introduction to functional grammar (4th ed.). London: Routledge. 
Heron, T. (2008). Globalization, neoliberalism and the exercise of human agency. International Journal of Politic, Culture and Society, 20, 85-101. http://dx.doi.org/10.1007/s10767-007-9019-z

INFACT (2004). Nestlé in Africa. Retrieved from http://www.babymilkaction.org/pdfs/infactnestleafrica04.pdf

Jessop, B. (2002). The future of the capitalist state. Cambridge: Polity Press.

Jessop, B. (2004). Critical semiotic analysis and cultural political economy. Critical Discourse Studies, 1(2), 154-174. http://dx.doi.org/10.1080/17405900410001674506

Kelsey, D., Mueller, F., Whittle, A., \& KhosraviNik, M. (2016). Financial crisis and austerity: Interdisciplinary concerns in critical discourse studies. Critical Discourse Studies, 13(1), 1-19. http://dx.doi.org/10.1080/17405904.2015.1074600

Kiely, R. (2000). Globalization: From domination to resistance. Third World Quarterly, 21(6), 1059-1070. http://dx.doi.org/10.1080/01436590020012043

Kress, G. (1996). Representational resources and the production of subjectivity: Questions for theoretical development of critical discourse analysis in a multicultural society. London: Routledge. In C. R. Caldas-Coulthard \& M. Coulthard (Eds.), Texts and practices: Readings in critical discourse analysis, 15-31.

Lee, D., \& Smith, N. J. (2010). Small state discourses in the international political economy. Third World Quarterly, 31(17), 1091-1105. http://dx.doi.org/10.1080/01436597.2010.518750

Lischinsky, A. (2011). In times of crisis: A corpus approach to the construction of the financial crisis annual Reports. Critical Discourse Studies, 8(3), 153-168. http://dx.doi.org/10.1080/17405904.2011.589231

Milanovic, B. (2016). Global inequality: A new approach for the age of globalization. Cambridge, MA: Harvard University Press.

Sayer, A. (2000). Realism and social science. London: Sage.

Shiller, R. J. (2008). The subprime solution: How today's global financial crisis happened, and what to do about it. Princeton, NJ: Princeton University Press.

Sum, N. L., \& Jessop, B. (2015). Towards a cultural political economy. Cheltenham: Edward Elgar.

The GRAIN (2011). The great milk robbery: How corporations are stealing livelihoods and a vital source of nutrition from the poor. Retrieved from http://www.grain.org/article/entries/4259.pdf

Yu, X. (2015). Language and state: A theory of the progress of civilization. Maryland, MD: University Press of America.

\section{(cc) $\mathrm{Br}$}

This work is licensed under a Creative Commons Attribution 3.0 License. 